\title{
Lindijer, C H 1998 - Postmodern Bestaan
}

Zoetermeer: Uitgeverij Boekencentrum

\section{Boekaankondiging}

Het etiket "postmodern" wordt vandaag te pas en te onpas op tal van zaken geplakt, soms zonder veel kennis van deze cultuur. Het is dan ook niet eenvoudig om te ontdekken wat postmodernisme precies inhoudt. De literatuur daarover is vaak diepzinnig en moeilijk te begrijpen.

In dit boek wil de auteur op een prettig, leesbare maar niet oppervlakkige manier informeren over deze stroming. Hij doet dat in vier delen.

In het eerste deel beschrijft hij het postmodernisme in al zijn uitingen, waaronder filosofie, letterkunde en architectuur. In deel twee komen twee stromingen aan de orde die op dezelfde crisis reageren als het postmodernisme: fundamentalisme en New Age. In het volgende deel tekent de auteur de facetten van het menszijn in een postmodeme tijd - onder andere leren leven met leegte, verzet tegen trends.

Het laaste deel is geheel gewijd aan postmoderne theologie en postmodern geloof. Hierin passeren verschillende theologen en auteurs de revue en wordt de postmoderne visie op enkele wezenlijke geloofsaspecten beschreven. De auteur besluit met een beschrijving van een mogelijke postmoderne geloofgemeenskap.

Dit boek vormt een belangrijke informatiebron over de heersende cultuur van vandaag en morgen. 